\title{
Efficacy of Trichoderma spp. against Common Fungal Pathogens
}

\author{
Sonja Tančić Živanov* · Radivoje Jevtić · Mirjana Lalošević · Dalibor Živanov · \\ Slađana Medić-Pap · Vesna Župunski
}

Institute of Field and Vegetable Crops, 21000 Novi Sad, Maksima Gorkog 30, Serbia

\begin{abstract}
Summary: Nowadays, organic food production demands more environmental friendly control of plant diseases. Biocontrol based on Trichoderma spp. usage is a promising due to Trichoderma is aggressive to broad range of phytopathogenic fungi. Given that, the aim of this study was to test in vitro antagonistic ability of ten native Serbian Trichoderma strains to ten common fungal pathogens. Study confirmed that Trichoderma spp. inhibits radial growth of Ascochyta pinodella (76.9\%), A. pinodes (60.0\%), A. pisi (68.5\%), Fusarium graminearum $(71.1 \%)$, F. proliferatum $(63.9 \%), F$. verticillioides (62.6\%), F. oxysporum (63.9\%), Macrophomina phaseolina $(63.8 \%)$, and Pyrenophora teres $(83.9 \%)$. These are first reports of Trichoderma spp. in vitro efficacy against $A$. pisi, $A$. pinodes, $A$. pinodella and $P$. teres. The lowest inhibitory effect was registered in dual cultures with Sclerotinia sclerotiorum - 52.2\%.
\end{abstract}

Key words: Ascochyta spp., Fusarium spp., M. phaseolina, P. teres, S. sclerotiorum, Trichoderma spp.

\section{Introduction}

The most common control methods of plant diseases that have been used so far are fungicide application in combination with host resistance to major pathogens. Nowadays, organic food production is in progress and demands more environmental friendly methods for dealing with devastating cosmopolitan pathogens such as Ascochyta pinodella, A. pinodes, A. pisi, Fusarium graminearum, $F$. proliferatum, $F$. verticillioides, $F$. oxysporum, Macrophomina phaseolina, Pyrenophora teres, and Sclerotinia sclerotiorum.

Farmers around the world are familiar with cosmopolitan aggressive pathogens, above all with Sclerotinia sclerotiorum (Lib.) de Bary and Fusarium species. S. sclerotiorum is known as a threat to numerous crops, such as: sunflower, soybean, oilseed rape, edible dry bean, chickpea, peanut, field pea, lentils and various vegetables as well (Bolton et al., 2006). S. sclerotiorum causes white rot of plants root, stem and fruit or pod, ending with complete plant wilting and rotting if infection starts early. In Serbia, Sclerotinia wilt is the most common form of Sclerotinia disease. Its average frequency on sunflower in Serbia is about $15-20 \%$, but

Corresponding author:

sonja.tancic@ifvcns.ns.ac.rs

Acknowledgements:

This research was part of the project TR31025 supported by Ministry of Education, Science and Technological Development of Republic of Serbia . in some years the frequency can reach even around 50\% (Marić et al., 1988).

Taxonomy of Fusarium species is complex, and up to 1000 species have been identified at times. Out of 101 most economically important plants, 81 have at least one plant associated with Fusarium disease (Moretti, 2009).Generally, Fusarium species can cause root, stem and ear rot which causes yield reductions estimated between $10 \%$ and $30 \%$ in Europe (Logrieco et al., 2002). Species of Liseola section, where F. verticillioides Sheldon and F. proliferatum (Matsushima Nirenberg) belong, are common in temperate regions mainly as pathogens of maize (Logrieco et al., 2002;), wheat (Furlong et al., 2005), barley (Bottalico, 1998), oat (Bottalico \& Perrone, 2002), hops (Stanković et al., 2008), sorghum (da Silva et al., 2006), asparagus (Elmer et al., 1999), etc. Maize, wheat and barley constitute almost $80 \%$ of European grain production, and another important pathogen of those crops, F. graminearum, is registered all over the world (Varga et al., 2002; Tomczak et al., 2002; Doohan et al., 2003; Tančić et al., 2009). Beside these crops, F. graminearum has been reported as pathogen of soybean (Dulić, 1987), rise (Nyvall et al., 1999), sorghum (Leslie et al., 1990), millet (Onyike et al., 1991) etc. F. oxysporum is also cosmopolitan species which can be isolated from deserts and tropical soils as well as from Arctic soils (Leslie \& Summerell, 2006). It is known as an important vascular wilt pathogen on numerous plant species worldwide, mainly vegetable crops of Solanaceae family (tomatoes, peppers, potatoes, eggplant), but also alfa-alfa (Krnjaja 
et al., 2007), sunflower (Tančić et al., 2012), soybean (Jasnić et al., 2005), sugarcane, legumes, lettuce, watermelon etc. (http://eol.org/pages/187980/hierarchy_entries/5733121 6/overview).

Another important pathogen common in mixed infections with F. oxysporum on sunflower and maize is $M$. phaseolina Tassi (Goid.) (Bhatti and Kraft, 1992). M. phaseolina is a soil borne pathogen with a wide host range which causes disease (charcoal rot) on more than 500 cultivated and wild plant species (https:// projects.ncsu.edu/cals/course/pp728/Macrophomina/ host.htm). This pathogen is prevalent in regions with arid subtropical and tropical climates, but it can be also registered in moderate climates when high temperature and dry conditions occurs. It is estimated that charcoal rot affects the crop throughout the world reducing seed yields by 20-36\% (Jimenéz-Diaz et al., 1983).

$P$. teres, causal agent of net blotch of barley, is a major disease worldwide that causes yield losses ranged from $10 \%$ to $40 \%$ (Ma et al., 2004). It is most severe in temperate regions of high rainfall and humidity, but epidemics can occur in low rainfall areas as well (Steffenson \& Webster, 1992). There are two types of symptoms caused by this pathogen: net-type lesions caused by $P$. teres $\mathrm{f}$. teres and spot-type lesions caused by $P$. teres $\mathrm{f}$. maculata. In recent years, epidemics of $P$. teres $\mathrm{f}$. maculata have occurred throughout the world (McLean et al., 2010), reducing grain quality parameters such as 1,000-grainweight by up to $19 \%$ (Jayasena et al., 2007).

Ascochyta blight is one of the most economically important diseases of pea and other legumes such as: faba bean, chick pea, grass pea, vetches, etc. (Peever et al., 2007; Barilli, 2016). Pathogens from this complex occur in all areas of the world where legumes are grown. Under favorable weather conditions, the average yield loss caused by Ascochyta blight is estimated above 50\% (McDonald and Peck, 2009). Ascochyta blight of pea, is caused by a complex of three pathogens: A. pisi Lib., A. pinodes (teleomorph: Mycosphaerella pinodes (Berk. \& Blox.) Vestergr.) and $A$. pinodella (L.K. Jones). Among them, $A$. pinodes is the most important one (Ali et al., 1978) and can cause yield reduction between 50 to $75 \%$ (Wallen, 1974).

Biocontrol of such devastating pathogens is a big challenge, but there is a great potential in Trichoderma spp. usage in these purposes. Presence of great variety of cellwall degrading enzymes and secondary metabolites makes Trichoderma strongly aggressive to broad range of phytopathogenic fungi (Vinale et al., 2008). When direct confrontation with pathogen occurs, the main biocontrol mechanisms of Trichoderma species are mycoparasitism and antibiosis (Howel, 2003). Trichoderma species are mainly soil fungi found in agricultural soils, native prairie, forests, salt marsh, desert soils of all climatic zones, but also in dead plant material, living roots of various plant species, seeds, lake water and air (Monte, 2001). World-wide distribution, fast growth and high spore production make those species easy to find and isolate. After all, it should be underlined that not all Trichoderma strains are effective, most of them are not, and some may even be phytotoxic or pathogenic (Menzies, 1993), so strain selection is of crucial importance.

Given that, the aim of this study was to test antagonistic ability of native Serbian Trichoderma isolates to ten common fungal pathogens ( $A$. pinodella, $A$. pinodes, $A$. pisi, F. graminearum, F. proliferatum, $F$. verticillioides, $F$. oxysporum, $M$. phaseolina, P. teres, and S. sclerotiorum).

\section{Material and Methods}

\section{Collection of isolates}

Samples of common pathogens were obtained from naturally infected plants from four different host plants, while Trichoderma spp. isolates were obtained from soil samples originating from different localities in Serbia (Table 1). The collection was formed throughout the period of $2009-2015$.

Table 1. Tested isolates data - isolate's code, origin, host plant and year of isolation

\begin{tabular}{|c|c|c|c|c|}
\hline Isolate code & Species & Origin & Host Plant / Substrate & Year of Isolation \\
\hline $\mathrm{ScSc}$ & S. sclerotiorum & Rimski Šančevi & sunflower & 2010 \\
\hline $\mathrm{MpH}$ & M. phaseolina & Bačka Topola & sunflower & 2009 \\
\hline $\mathrm{FOx}$ & F. oxysporum & Deliblato & sunflower & 2009 \\
\hline $\mathrm{FV}$ & F. verticillioides & Rimski Šančevi & maize & 2015 \\
\hline FP & F. proliferatum & Rimski Šančevi & maize & 2015 \\
\hline FG & F. graminearum & Rimski Šančevi & maize & 2014 \\
\hline PT & P. teres & Rimski Šančevi & barley & 2014 \\
\hline APs & A. pisi & Rimski Šančevo & Field pea & 2015 \\
\hline $\mathrm{APn}$ & A. pinodes & Novi Bečej & Field pea & 2014 \\
\hline $\mathrm{APl}$ & A. pinodella & Lukićevo & Field pea & 2014 \\
\hline TR1 & Trichoderma sp. & Rimski Šančevi & Soil sample & 2011 \\
\hline TR2 & Trichoderma sp. & Kuršumlija & Soil sample & 2012 \\
\hline TR3 & Trichoderma sp. & Rakovački potok & Soil sample & 2012 \\
\hline TR4 & Trichoderma sp. & Rimski Šančevi & Soil sample & 2012 \\
\hline TR5 & Trichoderma sp. & Belegiš & Soil sample & 2012 \\
\hline TR6 & Trichoderma sp. & Surduk & Soil sample & 2012 \\
\hline TR7 & Trichoderma sp. & Belegiš & Soil sample & 2012 \\
\hline TR8 & Trichoderma sp. & Surduk & Soil sample & 2012 \\
\hline TR9 & Trichoderma sp. & Surduk & Soil sample & 2012 \\
\hline TR10 & Trichoderma sp. & Surduk & Soil sample & 2012 \\
\hline
\end{tabular}



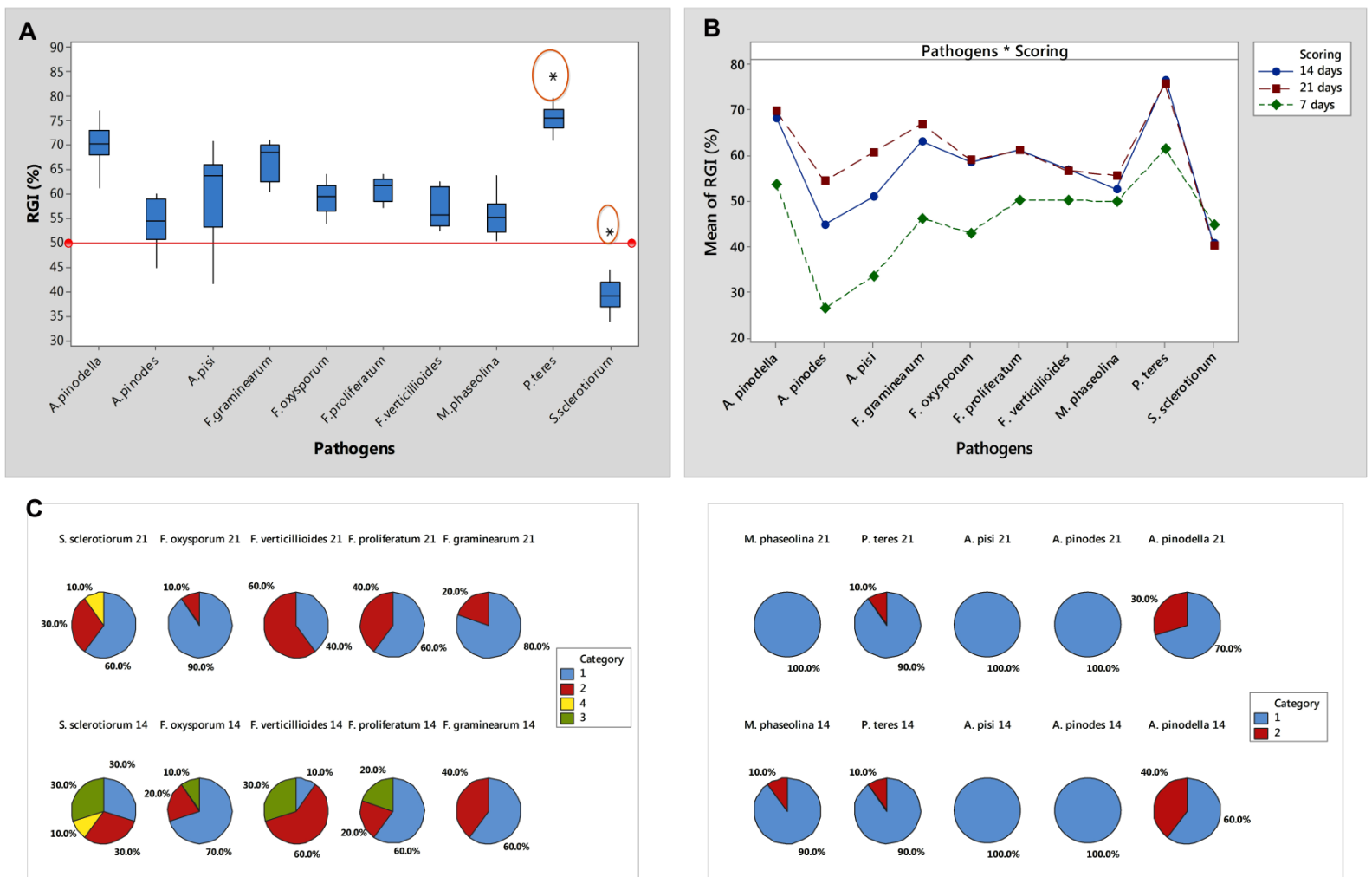

Figure 1. Antagonistic ability of Trichoderma spp. isolates against ten common pathogens measured by: (A) RGI on $21^{\text {st }}$ day of incubation in vitro, (B) RGI on $7^{\text {th }}, 14^{\text {th }}$ and $21^{\text {st}}$ day of incubation in vitro, (C) Bell's graduation on $14^{\text {th }}$ and $21^{\text {st }}$ day of incubation in vitro

\section{Isolation of the fungus}

Samples of maize ears, barley leaves, sunflower stems and heads, and field pea leaves and pods were collected from randomly chosen plants with typical disease symptoms. Pieces of infected tissue were placed on potato dextrose agar (PDA) medium amended with streptomycin and after seven days colonies with morphology and growth characteristics of Fusarium species, S. sclerotiorum, M. phaseolina, P. teres and Ascochyta species were selected for further purification. Suspensions of conidia or microsclerotia were dispersed on water-agar (WA) plates, and after 24 hours pure culture of each isolate were made by single spore or hyphal tip transfer technique (Leslie \& Summerell, 2006). These purified isolates were used for further analyses.

\section{Isolation of biocontrol agent}

Trichoderma spp. isolates were obtained from soil samples originating from different soil types and localities in Serbia, mainly from the Vojvodina Province. The representative soil samples were taken from the surface layer (0-20 cm depth) using soil probe. Selective water agar (WA) media amended with streptomycin was used to isolate Trichoderma spp. from soil samples by particle-plating method. Total of 20 soil pieces per sample were analysed seven days after incubation at room temperature. The emerging fungal colonies were observed under microscope, and transferred on suitable media for further analyses of morphological characters. For further research, all Trichoderma isolates were refined to single-spore isolates according to Leslie \& Summerell (2006).

\section{Dual Culture Test}

Dual culture test was used for screening of ten Trichoderma isolates antagonistic effect on ten different pathogens in vitro. Each Trichoderma isolate plug of 7 days old culture $\left(5 \mathrm{~mm}^{2}\right)$ was confronted with the pathogens isolate plug in $90 \mathrm{~mm}$ Petri plates at the 60 $\mathrm{mm}$ distance on PDA in four replicates. Antagonistic abilities of Trichoderma isolates were registered periodically on $7^{\text {th }}, 14^{\text {th }}$, and $21^{\text {st }}$ day of incubation in dark at $25^{\circ} \mathrm{C}$. After $21^{\text {st }}$ day of incubation, Radial Growth Inhibition (RGI) was calculated according to Rodriguez et al. (2000). Additionally, evaluation according to Bell was included (de Figueirêdo et al., 2010): 1 - Trichoderma sp. grows and covers completely all colonies of phytopathogen surface; 2 - Trichoderma sp. grows and covers $2 / 3$ of medium surface; 3 antagonist and phytopathogen colonize each one half of the medium surface and none seems to dominate each other; 4 - phytopathogen colonizes $2 / 3$ of surface medium; 5 - phytopathogen grows and covers completely all colonies of Trichoderma sp. and the medium surface. 


\section{Statistical analysis}

Factors that significantly influenced RGI were estimated using General Linear Model. For all analysis software Minitab 17 (trial version) was used.

\section{Results and Discussion}

Although Trichoderma species are mainly registered as an effective antagonists of many soil-borne pathogens on different crops this study shown that isolates of Trichoderma spp. which possess antagonistic ability against some pathogens are not effective against the others (Figure 1A). The significant influence of Trichoderma isolates and fungal species on RGI was confirmed with $\mathrm{P}=0.000$ and $\mathrm{P}=0.000$, respectively. Trichoderma spp. isolates were considered as effective when RGI exceeded $50 \%$. In addition, significant influence of scoring intervals $(\mathrm{P}=0.000)$ as well as interaction between pathogens and scoring intervals $(\mathrm{P}=0.000)$ on $\mathrm{RGI}$ was confirmed (Figure 1B). In order to have a better insight in antagonist-pathogen interactions Bell's graduation was used (Figure 1C).

In this study only 1 out of 10 isolates was proven to be effective in $S$. sclerotiorum mycelial growth inhibition (RGI above $50 \%$ ). This was consistent with studies of Joshiet al. (2010) who reported that only $10 \%$ of analysed Trichoderma isolates originating from Western Himalayas were effective in inhibition of mycelial growth of $S$. sclerotiorum. According to Joshi et al. (2010) inhibitory effect of tested Trichoderma spp. isolates is reported to be much higher than in this study. In contrast, Trichoderma isolates tested herein were highly effective against $P$. teres reaching RGI of $83.9 \%$ (Figure 1A). Generally, rapid growth of Trichoderma spp. isolates gives them important advantage over $P$. teres in the competition for space and nutrients, but more investigation should be done in order to explain the exact mechanism of inhibitory effect of Trichoderma isolates. Ali-Haimoudet al. (1993) reported that Trichoderma spp. were efficient antagonists of sclerotioid organ formation of Pyrenophora (syn. Drechslera) teres on barley.

In addition, results of this study are first report of Trichoderma spp. inhibiting activity on mycelial growth of A. pisi, A. pinnodes and A. pinnodella. So far, Trichoderma spp. antagonistic activity was mainly tested on Ascochyta rebiei, agent responsible for the anthracnose of chickpea. Benzohraet al. (2011) observed inhibiting action of T. harzianum on the mycelial growth of $A$. rebiei, followed by a complete stop of growth after the 7 th day and RGI varied from $20-70 \%$, which is similar to results presented in this work.

In this study, Trichoderma spp. isolates tested in dual culture with $M$. phaseolina expressed RGI between 50.6 - 63.8\% which is a bit more effective than RGI of $33.2-61.4 \%$ obtained in dual culture test reported by Singh et al. (2008).

Biocontrol of Fusarium spp. by Trichoderma species is mostly studied on F. oxysporum and effectiveness of
Trichoderma spp. against F. oxysporum f. sp. cubense (Thangavelu et al., 2004), F. oxysporum f. sp. adquki (John et al., 2010), F. oxysporum f. sp. vasinfectum (Zang et al., 1996), F. oxysporum f. sp. bycopersici (Cotxarrera et al., 2002), and F. oxysporum f. sp. phaseoli (Sallam et al., 2008) was proved in vitro. Maximal RGI in dual culture test with F. oxysporum f. sp. phaseoli was $51.4 \%$ (Sallam et al., 2008), while isolates tested herein were more effective considering that minimal RGI registered was 53.9\%. Potential antagonism of Trichoderma spp. to $F$. graminearum is tested in vitro by Foroutan (2013), and mycelial growth of $F$. graminearum was inhibited from $28.5-58.8 \%$ which is much lower than in this study (60.5 - 71.1\%). Additionally, effectiveness of Trichoderma species in contact growth inhibition of F. verticillioides was confirmed by Sempere \& Santamarina (2009) and Calistruet al. (1997) as well as in this study.

Figure $1 \mathrm{~B}$ indicates that there is no significant change in RGI scored on $14^{\text {th }}$ and $21^{\text {st }}$ day for $A$. pinodella, F. proliferatum, F. verticillioides, F. oxysporum, $P$. teres, and S. sclerotiorum while for other pathogens final RGI should be scored on $21^{\text {st }}$ day.

According to Figure $1 \mathrm{C}$, it can be noticed that Trichoderma spp. isolates covered colonies of tested phytopathogens surfaces until $14^{\text {th }}$ day: completely (grade 1), up to $2 / 3$ (grade 2) and half of surface (grade 3 ), while on $21^{\text {st }}$ day grades 1 and 2 dominated which classed Trichoderma isolates as effective competitors. The exception was one Trichoderma isolate which was dominated by S. sclerotiorum (grade 4, Figure 1C). More than $50 \%$ of tested isolates completely covered $S$. sclerotiorum colonies (grade 1) but contact inhibition did not stopped pathogens mycelia growth which resulted in low RGI on $14^{\text {th }}$ and $21^{\text {st }}$ day (Figure 1B). De Figueirêdo et al. (2010) reported that $37.5 \%$ of tested Trichoderma spp. isolates expressed satisfactory antagonism against $S$. sclerotiorum (grade 1), while 62.5\% expressed mild antagonism (grade 2). After all, in this study most Trichoderma spp. isolates expressed satisfactory antagonistic potential, especially against pathogens $M$. phaseolina, A. pisi, A. pinodes, $P$. teres and other than S. sclerotiorum.

\section{Conclusions}

Study confirmed that tested isolates of Trichoderma spp. are effective biocontrol agents against pathogens such as M. phaseolina, P. teres, Ascochyta complex and Fusarium spp. in vitro, and after additional tests and molecular identification, potentially can be used in biocontrol of those pathogens in vivo. These are first reports of Trichoderma spp. in vitro efficacy against $A$. pisi, $A$. pinodes, $A$. pinodella, and $P$. teres. After all, results of this study confirmed that $S$. sclerotiorum is still one of the most aggressive pathogens and remains as a big challenge for Trichoderma spp. and biocontrol. 


\section{References}

Ali, S. M., Nitschke, L. F., Dube, A. J., Krause, M. R., Cameron, B. (1978). Selection of pea lines for resistance to pathotypes of Ascochyta pinodes, A. pisi and Phoma medicaginis var. pinodella. Crop and Pasture Science, 29(4), 841-849.

Ali-Haimoud, D. E., Marrault, M., Albertini, L. (1993). Evaluation of organisms antagonistic to the sclerotioid organs of Drechslera teres, the causal agent of barley net blotch. Plant Disease, 77, 1251-1255.

Barilli, E., Cobos, M. J., Rubiales, D. (2016). Clarification on Host Range of Didymella pinodes the Causal Agent of Pea Ascochyta Blight. Frontiers in Plant Science, 7, 592.

Benzohra, I. E., Bendahmane, B. S., Labdi, M., Benkada, Y. (2011). In vitro Biocontrol Using the Antagonist Trichoderma harzianum Against the Algerian Isolates of Ascochyta rabiei (Pass.) Labr., the Agent of Ascochyta Blight in Chickpea (Cicer arietinum L.). International Journal of Microbiological Research, 2 (2), 124-128.

Bhatti, M. A., Craft, J. M., (1992). Influence of soil moisture on root rot and wilt of chickpea. Plant Disease, 76, 1259-1262.

Bolton, D. M., Thomma, B. P. H. J., Nelson, B. D. (2006). Sclerotinia sclerotiorum (Lib.) de Bary: biology and molecular traits of a cosmopolitan pathogen. Molecular Plant Pathology, 7(1), 1-16.

Bottalico, A. (1998). Fusarium Diseases of Cereals: Species Complex and Related Mycotoxin Profiles in Europe. Journal of Plant Pathology, 80 (2), 85-103.

Bottalico, A., Perrone, G. (2002). Toxigenic Fusarium species and mycotoxins associated with head blight in small-grain cereals in Europe. (A. Logrieco, J. A. Bailey, L. Corazza, B. M. Cooke eds.), Mycotoxins in Plant Disease. Kluwer Academic Publishers: 611-624.

Calistru, C., McLean, M., Berjak, P. (1997). In vitro studies on the potential for biological control of Aspergillus flavus and Fusarium moniliforme by Trichoderma species. Mycopathologia, 139, 115-121.

Cotxarrera, L., Trillas-Gay, M. I., Steinberg, C., Alabouvette, C. (2002). Use of sewage sludge compost and Trichoderma asperellum isolates to suppress Fusarium wilt of tomato. Soil Biology and Biochemistry, 34, 467-476.

Da Silva, V. N., Fernandes, F. M., Cirtez, A., Ribeiro, D. H., De Almeida, A. P., Hassegawa, R. H., Correa, B. (2006). Characterization and genetic variability of Fusarium verticillioides strains isolated from maize and sorghum in Brazil based on fumonisins production, microsatellites, mating type locus, and mating crosses. Canadian Journal of Microbilogy, 52(8), 798-804.

de Figueirêdo, G. S., de Figueirêdo, L. C., Cavalcanti, F. C. N., dos Santos, A. C., da Costa, A. F., de Oliveira, N. T. (2010). Biological and chemical control of Sclerotinia sclerotiorum using Trichoderma spp. and Ulocladium atrum and pathogenicity to bean plants. Brazilian Archives of Biology and Technology, 53 (1), 1-9.

Doohan, F. M., Brennan, J., Cooke, B. M. (2003). Influence Of Climatic Factors on Fusarium Species Pathogenic to Cereals. European Journal of Plant Pathology, 109, 755-768.

Dulić, K. (1987). Najčešće bolesti soje u Zemun Polju 1983. godine. Arbiv poljoprivrednih nauka 172,429-436.

Elmer, W. H., Summerell, B. A., Burgess, L. W., Nigh Jr. E. L. (1999). Vegetative compatibility groups in Fusarium prolifertum from asparagus in Australia. Mycologia, 91 (4), 650-654.

Foroutan, A. (2013). Evaluation of Trichoderma isolates for biological control of wheat Fusarium foot and root rot. Romanian Agricultural Research, 30, 335-342.

Furlong, E.B., Soares, L. M. V., Lasca, C. C., Kohara, E. Y. (2005). Mycotoxins and Fungi in Wheat Harvested During 1990 in Test Plots in the State of São Paulo, Brazil. Mycopathologia, 131(3), 185190.

Howel, C. R. (2003). Mechanisms employed by Trichoderma species in the biological control of plant diseases: the history and evolution of current concepts. Plant disease, 87, 4-10.

Jayasena, K. W., van Burgel, A., Tanaka, K., Mejewski, J., Loughman, R. (2007). Yield reduction in barley in relation to spot-type net blotch. Australasian Plant Pathology, 36, 429-433.

Jasnić, S. M., Vidić, M. B., Bagi, F. F., Đorđević, V. B. (2005). Pathogenicity of Fusarium Species In Soybean. Proceedings for Natural Sciences Matica Srpska Novi Sad, 109, 113-121.
Jimenéz-Diaz, R. M., Blanco-López, M. A., Sackston W. E. (1983). Incidence and distribution of charcoal rot of sunflower caused by Macrophomina phaseolina in Spain. Plant Disease, 63, 1033-1036.

John, R. P., Tyagi, R. D., Prévost, D., Brar, S. K., Pouleur, S., Surampalli, R.Y. (2010). Mycoparasitic Trichoderma viride as a biocontrol agent against Fusarium oxysporum f. sp. adzuki and Pythium arrhenomanes and as growth promoter of soybean. Crop Protection, 29, 1452-1459.

Joshi, B. B., Bhatt, R. P., Bahukhandi, D. (2010). Antagonistic and plant growth activity of Trichoderma isolates of Western Himalayas. Journal of Environmental Biology, 31(6), 921-928.

Krnjaja, V., Lević, J., Tomić, Z., Stanković, S. (2007). Diversity of vegetative compatibility of Fusarium oxysporum isolated from alfaalfa roots in Serbia. Journal of Mountain Agriculture on the Balkans, 10(5), 973-986.

Leslie, J. F., Pearson, C. A. S., Nelson, P. E., Tousoun, T. A. (1990). Fusarium species from corn, sorghum and soybean fields in the Central and Eastern United States. Phytopathology, 80, 343-350.

Leslie, J. F., Summerell, B. A. (2006). The Fusarium Laboratory Manual. Ames, IA, USA: Blackwell Publishing.

Logrieco, A., Mule, G., Moretti, A., Bottalico, A. (2002). Toxigenic Fusarium species and mycotoxins associated with maize ear rot in Europe. (A. Logrieco, J.A. Bailey, L. Corazza, B.M. Cooke, eds.), Mycotoxins in Plant Disease. Kluwer Academic Publishers: 597-609.

Ma, Z., Lapitan, N.L. V., Steffenson, B.J. (2004). QTL mapping of net blotch resistance genes in a doubledhaploid population of sixrow barley. Euphytica, 137(3), 291-296.

Marić, A., Čamprag, D., Maširević, S. (1988). White rot (Sclerotinia sclerotiorum). In: (Milošević S. ed.) Diseases and pests of sunflower and their control. Nolit, Belgrade, 69-83.

McDonald, G. K., Peck, D. (2009). Effects of crop rotation, residue retention and sowing time on the incidence and survival of ascochyta blight and its effect on grain yield of field peas (Pisum sativum L.). Field Crops Research, 111(1), 11-21.

McLean, M. S., Howlett, B. J., Hollaway, G. J. (2009). Epidemiology and control of spot form of net blotch (Pyrenophora teres $f$. maculata) of barley: a review. Crop Pasture Science 60, 303-315.

Menzies, J. G. (1993). A strain of Trichoderma viride pathogenic to germinating seedlings of cucumber, pepper and tomato. Plant Pathology,42, 784-791.

Monte, E. (2001). Understanding Trichoderma: Between biotechnology and microbial ecology. International Microbiology, 4, 1-4.

Moretti, A. (2009). Taxonomy of Fusarium Genus, a Continuous Fight Between Lumpers and Splitters. Proceedings for Natural Sciences Matica Srpska Novi Sad, 117, 7-13.

Nyvall, R. F., Percich, J. A., Mirocha, C. J. (1999): Fusarium head blight of cultivated and natural wild rise (Zizania palustris) in Minnesota caused by Fusarium graminearum and associated Fusarium spp. Plant disease 83, 159-164.

Onyike, N. B. N., Nelson, P. E., Marasas, W. F. O. (1991): Fusarium species associated with millet grain from Nigeria, Lesatho, and Zimbabwe. Mycologia 83, 708-712.

Peever, T. L., Barve, M. P., Stone, L. J., Kaiser, W. J. (2007). Evolutionary relationships among Ascochyta species infecting wild and cultivated hosts in the legume tribes Cicereae and Vicieae. Mycologia, 99(1), 59-77.

Sallam, N. M. A., Abo-Elyousr, K. A. M., Hassan, M. A. E. (2008). Evaluation of Trichoderma species as biocontrol agents for damping-off and wilt diseases of Phaseolus vulgaris L. and efficacy of suggested formula. Egyptian Journal of Phytopathology, 36(1-2), 8193.

Sempere, F., Santamarina, M. P. (2009). Antagonistic interactions between fungal rice pathogen Fusarium vericillioides (Sacc.) Nirenberg and Trichoderma barzianum Rifai. Annals of Microbiology, 59(2), 259-266.

Singh, V., Ranaware, A. M., Nimbkar, N. (2008). Bioefficacy of antagonists against root-rot fungus Macrophomina phaseolina of safflower. $7^{\text {th }}$ International Safflower Conference, 3-6 ${ }^{\text {th }}$ November 2008, Waga Waga, Australia.

Stanković, S., Lević, J., Petrović, T., Krnjaja, V. (2008). Mycotoxin production by Fusarium proliferatum and F. verticillioides isolated from hops in Serbia. Journal of Plant Pathology, 90 (3), 58. 
Steffenson, B. J., Webster, R. K. (1992). Pathotype diversity of Pyrenophora teres $\mathrm{f}$. teres on barley. Phytopathology, 82, 170-177.

Tančić, S., Dedić, B., Dimitrijević, A., Terzić, S., Jocić, S. (2012). Bioecological relations of sunflower pathogens - Macrophomina phaseolina and Fusarium spp. and sunflower tolerance to these pathogens. Romanian Agricultural Research, 29, 349-359.

Tančić, S., Stanković, S., Lević, J. (2009). Varijabilnost patogenih svojstava Fusarium spp. poreklom iz zrna pšenice i kukuruza. Pesticides \& Phytomedicine, 24(4), 259-269.

Thangavelu, R., Palaniswami, A., Velazhahan, R. (2004). Mass production of Trichoderma harzianum for managing fusarium wilt of banana. Agriculture, Ecosystems \& Environment, 103, 259-263.

Tomczak, M., Wiśniewska, H., Stępień, Ł., Kostecki, M., Chelkowski, J., Goliński, P. (2002). Deoxynivalenol, Nivalenol and Moniliformin in Wheat Samples with Head Blight (Scab) Symptoms in Poland (1998-2000). In: Mycotoxins in Plant Disease (A. Logrieco, J. A. Bailey, L. Corazza, B.M. Cooke eds). European Journal of Plant Pathology, 108, 625 - 630. Kluwer Academic Publishers.
Varga, J., Tóth, B., Mesterházy, Á., Téren, J., Fazekas, B. (2002). Mycotoxigenic fungi and mycotoxins in foods and feeds in Hungary. In: An Overview on Toxigenic Fungi and Mycotoxins in Europe (A. Logrieco i A. Visconti eds). Kluwer Academic Publishers, London, 123 - 139.

Vinale, F., Sivasithamparam, K., Ghisalberti, E., Marra, R., Woo, S. L., Lorito, M. (2008). Trichoderma - plant - pathogen interactions. Soil Biology \& Biochemistry, 40, 1-10.

Wallen, V. R. (1974). Influence of three ascochyta diseases of peas on plant development and yield. Canadian Plant Disease Survey, 54, 86-90.

Zang, J., Howell, C. R., Starr, J. L. (1996). Suppression of Fusarium colonization of cotton roots and Fusarium wilt by seed treatments with Gliocladium virens and Bacillus subtilis. Biocontrol Sciences and Technology, 6, 175-187.

http://eol.org/pages/187980/hierarchy_entries/57331216/overview [retrieval date: 06.03.2017.]

https://projects.ncsu.edu/cals/course/pp728/Macrophomina/ host.htm [retrieval date: 06.03.2017.]

\section{Efikasnost Trichoderma spp. izolata protiv najčešćih gljivičnih patogena}

\section{Sonja Tančić Živanov · Radivoje Jevtić · Mirjana Lalošević . Dalibor Živanov · Slađana Medić-Pap · Vesna Župunski}

Sažetak: U današnje vreme, organska proizvodnja sve više zahteva primenu ekoloških metoda u suzbijanju biljnih bolesti. Biološka kontrola bazirana na upotrebi Trichoderma vrsta obećava jer su Trichoderma vrste izuzetno agresivne prema velikom broju fitopatogenih gljiva. Stoga je cilj ovih istraživanja bio da se in vitro testira antagonističko dejstvo deset Trichoderma spp. izolata poreklom iz Srbije na deset ekonomski značajnih fitopatogenih gljiva. Istraživanja su potvrdila da su testirani izolati Trichoderma spp. inhibirali radijalni porast vrsta do: Ascochyta pinodella (76,9\%), A. pinodes (60,0\%), A. pisi (68,5\%), Fusarium graminearum (71,1\%), F. proliferatum (63,9\%), F. verticillioides (62,6\%), F. oxysporum (63,9\%), Macrophomina phaseolina (63,8\%) i Pyrenophora teres (83,9\%). Najniža inhibicija porasta patogena je registrovana u dvojnim kulturama sa vrstom $S$. sclerotiorum - do 52,2\% inhibicije.

Ključne reči: Ascochyta spp., Fusarium spp., M. phaseolina, P. teres, S. sclerotiorum, Trichoderma spp. 